\title{
Inhibitory effect of vitamin K1 on growth and polyamine biosynthesis of human gastric and colon carcinoma cell lines
}

\author{
MICHELE LINSALATA $^{1 *}$, ANTONELLA ORLANDO $^{1 *}$, VALERIA TUTINO $^{2}$, \\ MARIA NOTARNICOLA ${ }^{2}$, BENEDETTA D'ATTOMA ${ }^{1}$ and FRANCESCO RUSSO ${ }^{1}$ \\ ${ }^{1}$ Laboratory of Nutritional Pathophysiology, ${ }^{2}$ Laboratory of Nutritional Biochemistry, National Institute \\ for Digestive Diseases, I.R.C.C.S. 'Saverio de Bellis', Castellana Grotte, 70013 Bari, Italy
}

Received March 6, 2015; Accepted April 27, 2015

DOI: 10.3892/ijo.2015.3033

\begin{abstract}
Gastric and colon cancers remain the leading cause of cancer mortality throughout the world. Since the gastrointestinal tract works in a constant link with the external environment, chemoprevention by dietary constituents could represent a possible approach to reduce cancer risk. Dietary vitamin K1 (VK1) has been shown to prevent the growth of many types of cancer cells. However, no data are available on possible different susceptibility to VK1 by gastric or colon neoplastic cell lines. Moreover, the exact mechanism of action of VK1 is still object of investigation, even if it has been reported that VK1 may induce cell cycle arrest and apoptosis. Therefore, molecules affecting cell growth such as the natural polyamines could be of interest in VK1 action. The aim of the present study was to investigate the effects of increasing concentrations of VK1 (from 10 to $200 \mu \mathrm{M}$ ) administered up to $72 \mathrm{~h}$, on the cell proliferation and apoptosis of a gastric (HGC-27) and a colon (SW480) cancer cell line. Additionally, the polyamine biosynthesis and the MAPK pathway were also examined. VK1 treatments caused an inhibition of cell proliferation and an induction of apoptosis in both cell lines, with a concomitant significant decrease of the polyamine biosynthesis, increased phospho-ERK 1/2 expression was also observed. A different proliferative behavior and a different response to VK1 by gastric and colon cancer cells was evident, with colon cells showing a more pronounced susceptibility to VK1 action. VK1 is safe and without known toxicities in adult humans, consequently it could be effective in prevention and treatment of selected gastrointestinal neoplasms. Protocols
\end{abstract}

Correspondence to: Dr Francesco Russo, Laboratory of Nutritional Pathophysiology, National Institute for Digestive Diseases, I.R.C.C.S. 'Saverio de Bellis', Via Turi 27, Castellana Grotte, 70013 Bari, Italy

E-mail: francesco.russo@irccsdebellis.it

${ }^{*}$ Contributed equally

Key words: chemoprevention, colon cancer, gastric cancer, ornithine decarboxylase, polyamines, vitamin $\mathrm{K} 1$ based on the use of VK1, along with polyamine inhibitors and/or analogues, could represent a suitable alternative option for improving the efficacy of chemoprevention and treatment in future strategies for gastrointestinal cancer management.

\section{Introduction}

Gastric and colon cancers remain the leading cause of cancer mortality throughout the world. Overall, neoplasms of the gastrointestinal (GI) tract account for $25 \%$ of all neoplasms and for $9 \%$ of deaths from all causes in the world (1). Therefore, chemoprevention by dietary constituents is gaining interest as a possible approach to reduce cancer risk (2). The GI tract works in a constant link with the external environment and modifications in the diet may amplify or prevent exposure to carcinogenetic factors. In this context, identifying dietary components with antineoplastic activity and investigating their mechanisms of action are assuming importance in a new strategy of prevention for blocking or, at least, delaying GI cancer onset $(2,3)$.

Among the substances naturally found in foods, evidence suggests that dietary vitamin $\mathrm{K}(\mathrm{VK})$ compounds are able to prevent the growth of many types of cancer cells, as demonstrated by studies performed in both in vitro and in vivo models (4-7).

VK is the family name for a series of fat-soluble compounds, classically associated to bone health and metabolism and in regulation of blood clotting (8). There are two structurally related natural forms of vitamin K: the vitamin K1 (VK1), phylloquinone and the vitamin $\mathrm{K} 2$ (VK2), menaquinone. The first is mainly found in green leafy vegetables, the latter is synthesized by the intestinal flora. Another compound, the vitamin K3 (VK3), menadione, is not considered a natural VK, but rather a synthetic analogue acting as a provitamin (8).

Most of data on the antineoplastic effects of VK family derives from studies performed on VK2 and VK3 and the treatment of hepatocellular carcinoma (9-11). As regards VK1, it has been proven to be effective in glioma and pancreatic cancer cell lines $(12,13)$. However, in spite of its features as a nutritional factor, the potential of VK1 against neoplasms of the GI tract has received less or no attention so far (14). In addition, the exact mechanism of action of VK family in affecting the neoplastic growth is still object of investigation, even if it has 
been reported that VK compounds may alter the expression of some genes involved in cell cycle control and induce apoptosis in different cancer cell lines $(15,16)$. A number of molecules, such as the natural polyamines: putrescine, spermidine and spermine, could be of interest in VK action. Polyamines are ubiquitous short-chain polycationic alkylamines actively involved in cell proliferation and differentiation. They interact with anionic macromolecules including DNA, RNA and protein, thereby modulating chromatin structure, gene transcription, translation and DNA stabilization (17). Moreover, it has been demonstrated that polyamines are also involved in signal transduction and in cell death pathway (18).

The rise in intracellular polyamine concentration, mostly occurring through an upregulation of the biosynthetic enzyme ornithine decarboxylase (ODC), correlates with increased cell proliferation and tumorigenesis (19). Thus, the mucosal polyamine levels can be considered markers for neoplastic proliferation (20). As a consequence, not only polyamine deprivation, but also impairment of polyamine uptake into neoplastic cells and modulation of the polyamine metabolic pathway, can represent a way of cancer chemoprevention and chemotherapy (21). Drugs that affect polyamine biosynthesis and catabolism have been extensively evaluated in both in vitro and in vivo studies as possible alternative tools for the management of cancer (22). Besides, some components of diet, particularly flavonoids, polyphenols and probiotics, have already been reported to reduce the hyperproliferative role of polyamines in GI neoplasms (23-25). On the contrary, the polyamine pathway as potential target for dietary VK has not been evaluated and no data are available on possible different susceptibility to VK1 by gastric or colon neoplastic cell lines.

In order to shed light on how VK1 could affect the growth of neoplasms originating from different GI tracts, the aim of the present study was to evaluate and compare the effects of increasing concentrations of VK1 on the cell proliferation and apoptosis of a gastric (HGC-27) and a colon (SW480) cancer cell line. Additionally, to investigate which mechanisms could be involved in affecting cell growth, the polyamine biosynthesis, as well as the phospho-ERK 1/2 (P-ERK 1/2) expression, were examined in the same cell lines. The latter signaling molecule has been linked to the regulation of cellular growth, apoptosis and chemoresistance (26).

\section{Materials and methods}

Cell culture conditions. HGC-27 cell line (neoplastic cells from undifferentiated carcinoma of the stomach) and human colon adenocarcinoma-derived SW480 cell line (low differentiated cells derived from colonic adenocarcinoma grade III-IV) were obtained from the Interlab Cell Line Collection (Genoa, Italy). As previously published (27), cells were routinely cultured in Dulbecco's modified Eagle's medium (DMEM) and Leibovitz L-15 medium, respectively, supplemented with $10 \%$ fetal bovine serum (FBS), $2 \mathrm{mM}$ glutamine, $100 \mathrm{U} / \mathrm{ml}$ penicillin, $100 \mu \mathrm{g} / \mathrm{ml}$ streptomycin in a monolayer culture and incubated at $37^{\circ} \mathrm{C}$ in a humidified atmosphere containing $5 \% \mathrm{CO}_{2}$ in air. At confluence, the cells were harvested by trypsinization and serially sub-cultured with a 1:4 split ratio. All cell culture components were purchased from Sigma-Aldrich (Milan, Italy).
Vitamin K1 treatment. HGC-27 and SW480 cells (25th-30th passage) were seeded at a density of $2 \times 10^{5}$ cells $/ 5 \mathrm{ml}$ of supplemented Leibovitz L-15 and DMEM medium, respectively, in 60-mm tissue culture dishes (Corning Costar Co., Milan, Italy). After $24 \mathrm{~h}$, to allow for attachment, the medium was removed and supplemented culture medium containing increasing concentrations of VK1 $(10,50,100$ and $200 \mu \mathrm{M})$ added to cells for 24,48 and $72 \mathrm{~h}$. Triplicate cultures were set up for each treatment and for the control, and each experiment was repeated 4 times. In the set of experiments investigating the role of ERK 1/2 on the VK1-induced apoptosis, the cells were treated with $20 \mu \mathrm{M}$ MEK inhibitor (UO126) $2 \mathrm{~h}$ prior to 100- and 200- $\mu \mathrm{M}$ VK1 treatment.

Assessment of cell proliferation. After HGC-27 and SW480 cells had been cultured for 24,48 and $72 \mathrm{~h}$ with increasing concentrations of $\mathrm{VK} 1$, the proliferative response was measured by colorimetric 3-(4,5 di-methylthiazol-2-yl)2,5-diphenyltetrazolium bromide (MTT) test.

To determine cell growth by colorimetric test, MTT stock solution $(5 \mathrm{mg} / \mathrm{ml}$ in medium) was added to each dish at a volume of one tenth the original culture volume and incubated for $2 \mathrm{~h}$ at $37^{\circ} \mathrm{C}$ in humidified $\mathrm{CO}_{2}$. At the end of the incubation period, the medium was removed, and the blue formazan crystals were solubilized with acidic isopropanol $(0.1 \mathrm{~N} \mathrm{HCl}$ absolute isopropanol). MTT conversion to formazan by metabolically viable cells was monitored by spectrophotometer at an optical density of $570 \mathrm{~nm}(28)$.

Apoptosis. The apoptosis was measured by evaluation of Bax and Bcl-2 mRNA expression [using quantitative PCR (qPCR) method with SYBR1-Green dye] and protein expression of Bax, Bcl-2, caspase-3, caspase-9 and P-ERK 1/2 (using western blot analysis).

Cells were washed twice in phosphate-buffered saline (PBS) and then trypsinized and centrifuged at $280 \mathrm{x} \mathrm{g}$. The cell pellets were re-suspended in $0.3 \mathrm{ml}$ of pure distilled water and used for RNA extraction. Total cell RNA was extracted using TRI Reagent (Molecular Research Center, Inc., Cincinnati, OH, USA), following the manufacturer's instructions. Approximately $2 \mu \mathrm{g}$ total cell RNA, extracted from both the control and treated cells, was used for cDNA synthesis. Reverse transcription (RT) was carried out in $20 \mu \mathrm{l}$ of the final volume at $41^{\circ} \mathrm{C}$ for $60 \mathrm{~min}$, using $30 \mathrm{pmol}$ antisense primers for analyses of Bax, Bcl-2 and $\beta$-actin gene (28). The $\beta$-actin gene was utilized as an internal control and it was chosen as a reference housekeeping gene. Real-time PCRs were performed in $25 \mu \mathrm{l}$ of final volume containing $2 \mu \mathrm{l}$ of cDNA, Master Mix with SYBR-Green (iQ SYBR Green Supermix; Bio-Rad Laboratories, Milan, Italy) and sense and antisense primers for Bax, Bcl-2 and $\beta$-actin gene.

Real-time PCRs were carried out in a CFX96 Real-Time PCR detection system (Bio-Rad Laboratories) using the following protocol: 45 cycles at $95^{\circ} \mathrm{C}$ for $3 \mathrm{~min}, 95^{\circ} \mathrm{C}$ for $10 \mathrm{sec}, 55^{\circ} \mathrm{C}$ for $30 \mathrm{sec}$ followed by a melting curve step at $65-95^{\circ} \mathrm{C}$ with a heating rate of $0.5^{\circ} \mathrm{C}$ per cycle for 80 cycles. The PCR products were quantified by external calibration curves, one for each tested gene. Curves were obtained with serial dilutions of known copy number of molecules $\left(10^{2}-10^{7}\right.$ molecules). All expression data were normalized by dividing 
the target amount by the amount of $\beta$-actin. The specificity of the PCR product was confirmed by gel electrophoresis.

For western blotting, HGC-27 and SW480 cells were collected and lysed on ice in RIPA buffer (Pierce Ripa buffer; Thermo Fisher Scientific, Rockford, IL, USA). After homogenization and centrifugation at $14,000 \mathrm{rpm}$ for $15 \mathrm{~min}$ at $4^{\circ} \mathrm{C}$, protein concentration was measured by a standard Bradford assay (Bio-Rad Laboratories). Aliquots of $50 \mu \mathrm{g}$ of total proteins were separated in $4-12 \%$ pre-cast polyacrylamide gels (Invitrogen, Life Technologies, Carlsbad, CA, USA) and transferred onto a PVDF membrane (Bio-Rad Laboratories) with the Trans-Blot Turbo (Bio-Rad Laboratories). Bax, Bcl-2, caspase-3, caspase-9, P-ERK $1 / 2$ and $\beta$-actin protein expressions were evaluated by 1:500 diluted Bax, Bcl-2 (D55G8), cleaved caspase-3 (Asp175), caspase-3 (3G2), cleaved caspase-9, caspase-9, phospho-p44/42 mitogen-activated protein kinase (MAPK) (ERK 1/2) (197G2), p44/42 MAPK (L34F12) and $\beta$-actin antibody, respectively (Cell Signaling Technology, Danvers, MA, USA). After overnight incubation, the membranes were further incubated with a horseradish peroxidase-conjugated goat secondary antibody (Bio-Rad Laboratories). The proteins were detected by chemiluminescence (ECL; Thermo Fisher Scientific). The densitometric analysis of each protein-related signal was obtained by using the Molecular Imager ChemiDoc ${ }^{\mathrm{TM}}$ (Bio-Rad Laboratories) and normalized against $\beta$-actin expression.

Polyamine biosynthesis. For the evaluation of polyamine levels after VK1 treatment, each cell culture pellet was homogenized in $700 \mu \mathrm{l}$ of $0.9 \%$ sodium chloride mixed with $10 \mu \mathrm{l}(200 \mathrm{nmol} / \mathrm{ml})$ of the internal standard 1,10-diaminodecane (1,10-DAD). An aliquot of the homogenate was used to measure the total protein content. Then, to precipitate proteins, $50 \mu \mathrm{l}$ of perchloride acid (PCA) $3 \mathrm{M}$ was added to the homogenate. After $30 \mathrm{~min}$ of incubation in ice, the homogenate was centrifuged for $15 \mathrm{~min}$ at 7,000 $\mathrm{x} \mathrm{g}$. The supernatant was filtered (Millex-HV13 pore size $0.45 \mu \mathrm{m}$; Millipore, Bedford, MA, USA) and lyophilized. The residue was dissolved in $300 \mu \mathrm{l}$ of $\mathrm{HCl}(0.1 \mathrm{~N})$. Dansylation and the extraction of dansyl-polyamine derivatives were performed as previously described (29). After extraction, aliquots of $200 \mu \mathrm{l}$ were injected into a high-performance liquid chromatography system (UltiMate 3000; Dionex Corp., Sunnyvale, CA, USA) equipped with a reverse-phase column (Sunfire C18, 4.6x100 mm, $3.5 \mu \mathrm{m}$ particle size; Waters Corp., Milford, MA, USA). Polyamines were eluted with a linear gradient ranging from acetonitrile-water $(50: 50, \mathrm{v}: \mathrm{v})$ to acetonitrile $(100 \%)$ for $30 \mathrm{~min}$. The flow was $0.5-1.0 \mathrm{ml} / \mathrm{min}$ from 0 to $12 \mathrm{~min}$ and then set at a constant rate $(1.0 \mathrm{ml} / \mathrm{min})$ until the 30 th $\mathrm{min}$. The fluorescent intensity was monitored by a fluorescence detector (UltiMate $3000 \mathrm{RS}$; Dionex Corp.) with excitation at $320 \mathrm{~nm}$ and emission at $512 \mathrm{~nm}$. Polyamine levels were expressed as concentration values in $\mathrm{nmol} / \mathrm{mg}$ of protein.

ODC activity was measured with a radiometric technique that estimated the amount of ${ }^{14} \mathrm{CO}_{2}$ liberated from DL- $\left[1-{ }^{14} \mathrm{C}\right]$-ornithine (specific activity, $56.0 \mathrm{mCi} / \mathrm{mmol}$; New England Nuclear, Boston, MA, USA) (30). The cell culture pellet $\left(2-4 \times 10^{6}\right.$ cells $)$ was homogenized in $0.6 \mathrm{ml}$ ice-cold Tris-HCl (15 mM, pH 7.5) containing $2.5 \mathrm{mM}$ dithiothreitol, $40 \mu \mathrm{M}$ pyridoxal-5-phosphate, and $100 \mu \mathrm{M}$ ethylene diamine tetra acetate and then centrifuged at $30,000 \times \mathrm{g}$ for $30 \mathrm{~min}$ at $4^{\circ} \mathrm{C}$. An aliquot of supernatant $(200 \mu \mathrm{l})$ was added to a glass test tube containing $0.05 \mu \mathrm{Ci} \mathrm{DL}-\left[1-{ }^{14} \mathrm{C}\right]$-ornithine and $39 \mathrm{nmol}$ DL-ornithine. After incubation for $60 \mathrm{~min}$ at $37^{\circ} \mathrm{C}$, the reaction was stopped by adding trichloroacetic acid (TCA) to a final concentration of $50 \% .{ }^{14} \mathrm{CO}_{2}$ liberated from DL- $\left[1-{ }^{14} \mathrm{C}\right]$-ornithine was trapped on filter paper pre-treated with $40 \mu 1 \mathrm{NaOH}(2 \mathrm{~N})$, which was suspended in a center well above the reaction mixture. Radioactivity on the filter papers was determined by a liquid scintillation counter (model 1219 Rackbeta; Pharmacia LKB Biotechnology AB, Uppsala, Sweden). ODC activity was expressed as $\mathrm{pmolCO}_{2} / \mathrm{h} / \mathrm{mg}$ of protein. Enzymatic activity was found to be linear within the range of $50-600 \mu \mathrm{g}$ of protein $(\mathrm{r} 2=0.99)$. The intra-assay and inter-assay variation coefficients (CV\%) were 6 and $8 \%$, respectively.

The effects of VK1 treatments on ODC mRNA levels were evaluated using the above described quantitative PCR method with SYBR1-Green dye and the appropriate primers.

Statistical analysis. Due to the non-normal distribution of the data, non-parametric tests were performed. Data were analyzed by Kruskal-Wallis analysis of variance and Dunn's multiple comparison test. All data are expressed as mean \pm SEM. Differences were considered significant at $\mathrm{P}<0.05$. The software package SigmaStat for Windows, version 3.00 (SPSS, Inc., San Jose, CA, USA) was used.

\section{Results}

Effects of VK1 on cell proliferation. Fig. 1 reports the effects of exposure of HGC-27 and SW480 cell lines to increasing concentrations of VK1 (namely 10, 50, 100 and $200 \mu \mathrm{M}$ ) for 24,48 and $72 \mathrm{~h}$. VK1 produced considerable antiproliferative effects in both cell lines.

In particular, VK1 administration caused a significant $(\mathrm{P}<0.05)$ reduction in the conversion of the MTT tetrazolium salt in HGC-27 cells compared to untreated control with concentrations starting from $100 \mu \mathrm{M}$ after 48 and $72 \mathrm{~h}$ of treatment (-13 and $-28 \%$, respectively) (Fig. 1A).

In SW480 colon cancer cells this effect was more evident $(-59 \%)$ and started earlier, after $24 \mathrm{~h}$ of $100 \mu \mathrm{M}$ treatment (Fig. 1B). After $72 \mathrm{~h}, \mathrm{VK} 1$ concentrations $\geq 50 \mu \mathrm{M}$ were able to cause a significant and marked reduction $(-62 \%)$ of cell proliferation $(\mathrm{P}<0.05)$.

Effects of VK1 on apoptosis. Fig. 2 shows the effects of increasing VK1 concentrations on apoptosis of the HGC-27 and SW480 cell lines, evaluated by Bax and Bcl-2 mRNA levels and expressed as $\mathrm{Bax} / \mathrm{Bcl}-2$ ratio.

HGC-27 cell line exhibited a significant $(\mathrm{P}<0.05)$ and dramatic increase in the $\mathrm{Bax} / \mathrm{Bcl}-2$ ratio at $48 \mathrm{~h}$ and with the highest concentrations of VK1 (100 and $200 \mu \mathrm{M})$ compared to control cells $(+343$ and $+522 \%$, respectively) (Fig. $2 \mathrm{~A}$ ). Similarly, in SW480 cells a significant $(\mathrm{P}<0.05)$ and even more dramatic increase in the Bax/Bcl-2 ratio was evident at $48 \mathrm{~h}$ and with the highest concentrations of VK1 (100 and $200 \mu \mathrm{M})$ compared to control cells ( +750 and $+500 \%$, respectively) (Fig. 2B). The induction of apoptosis continued to be significant after $72 \mathrm{~h}$ of treatment with the concentration of $100 \mu \mathrm{M}$ 
A

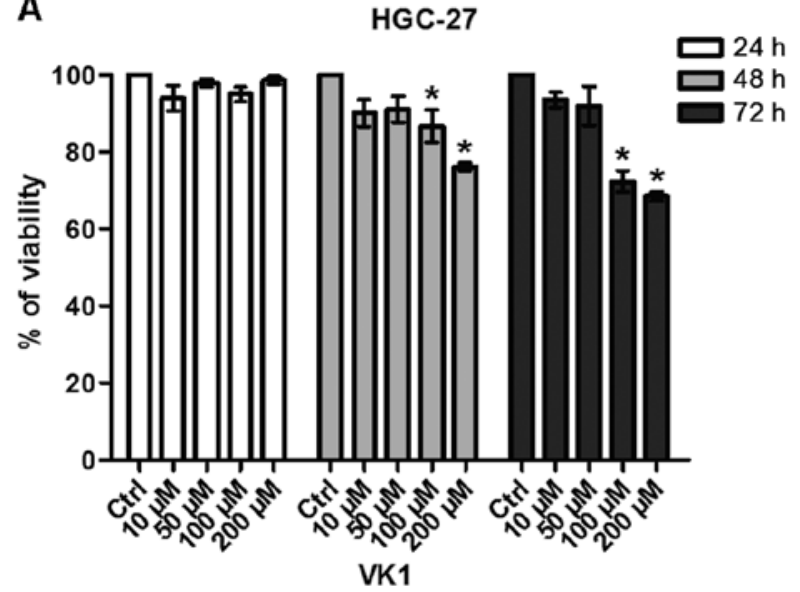

B

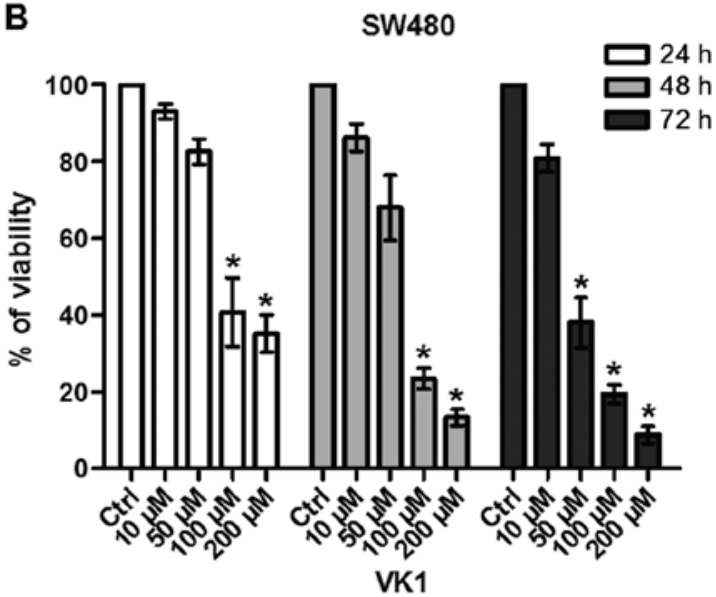

Figure 1. Proliferative response of HGC-27 and SW480 cell lines to vitamin K1 (VK1) treatment. Effects of increasing concentrations of VK1 (10, 50 , 100 and $200 \mu \mathrm{M}$ ) on the conversion of MTT tetrazolium salt in HGC-27 (A) and SW480 (B) cell lines after 24,48 and $72 \mathrm{~h}$ of treatment. All data represent the result of four different experiments (mean \pm SEM). For each time of treatment, data were analyzed by Kruskal-Wallis analysis of variance and Dunn's multiple comparison test. ${ }^{*} \mathrm{P}<0.05$ compared to control cells.

A

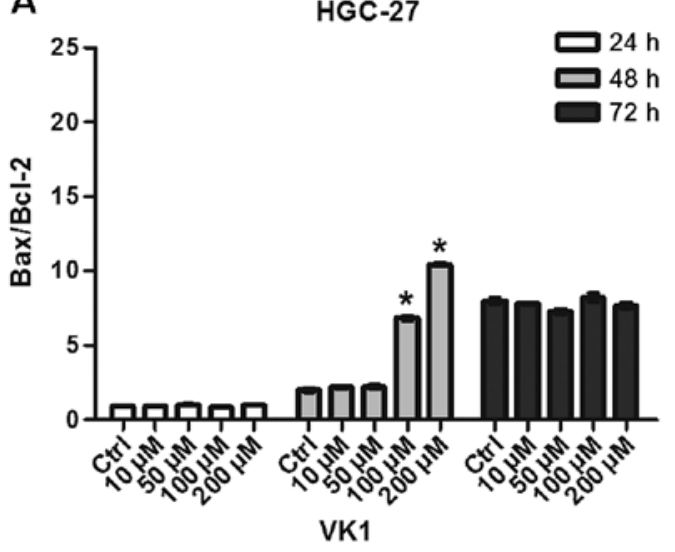

B

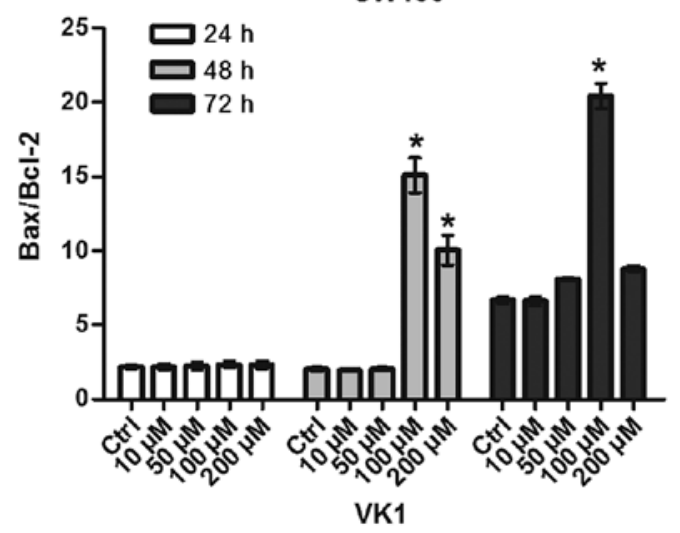

Figure 2. Apoptotic response of HGC-27 and SW480 cell lines to vitamin K1 (VK1) treatment. Effects of increasing concentrations of VK1 (10, 50 , 100 and $200 \mu \mathrm{M}$ ) on the Bax/Bcl-2 mRNA level in HGC-27 (A) and SW480 (B) cell lines after 24, 48 and $72 \mathrm{~h}$ of treatment. All data represent the result of four different experiments (mean \pm SEM). For each time of treatment, data were analyzed by Kruskal-Wallis analysis of variance and Dunn's multiple comparison test. ${ }^{*} \mathrm{P}<0.05$ compared to control cells.

$(+300 \%)$, while the Bax/Bcl-2 ratio dramatically decreased by $42 \%$ with the highest $200 \mu \mathrm{M}$ concentration, probably as a consequence of VK1 toxic effect.

The protein levels of Bax, Bcl-2, caspase-3 and caspase-9 were evaluated by western blot analysis. In HGC-27 cells, no significant changes in Bax and $\mathrm{Bcl}-2$ proteins or in $\mathrm{Bax} / \mathrm{Bcl}-2$ ratio occurred at all the times and concentrations used (data not shown). On the contrary, an increase in apoptotic proteins was observed only after $48 \mathrm{~h}$ of treatment in SW480 cells (Fig. 3A). More specifically, Bax protein significantly $(\mathrm{P}<0.05)$ increased by $\sim 200 \%$ in cells treated with VK1 concentrations $\geq 100 \mu \mathrm{M}$ compared to untreated cells (Fig. 3B). Bcl-2 significantly $(\mathrm{P}<0.05)$ decreased by $50 \%$ with $\mathrm{VK} 1$ concentrations $\geq 10 \mu \mathrm{M}$ compared to control cells (Fig. $3 \mathrm{C})$. A significant $(\mathrm{P}<0.05)$ $200 \%$ increase in the $\mathrm{Bax} / \mathrm{Bcl}-2$ ratio was observed with $\mathrm{VK} 1$ concentrations equal to 50 and $100 \mu \mathrm{M}$ compared to untreated cells (Fig. 3D). With the highest $200 \mu \mathrm{M}$ concentration, Bax/ Bcl-2 ratio dramatically increased by $400 \%$ compared to control cells. Of note, the addition of UO126 blocked the
VK1 mediated induction of apoptosis in SW480 colon cancer cells.

As for the involvement of caspases in VK1-induced apoptosis, no significant cleavage of caspase-3, an executioner caspase, or caspase-9, an initiator caspase, was observed in the two cell lines. This evidence suggests that VK1 may induce apoptosis in these cells without activation of caspases (data not shown).

P-ERK 1/2 phosphorylation was evaluated by treating cells with increasing VK1 concentrations (from 10 to $200 \mu \mathrm{M}$ ) for 24,48 and $72 \mathrm{~h}$. No variation, at all the tested times was observed in P-ERK 1/2 in HGC-27 cells (data not shown). On the contrary, a dose-dependent significant $(\mathrm{P}<0.05)$ increase in P-ERK 1/2 was observed only after $48 \mathrm{~h}$ in SW480 cells with VK1 concentrations starting from $10 \mu \mathrm{M}(+100 \%)$ (Fig. 4). When cells were pretreated for $2 \mathrm{~h}$ with $20 \mu \mathrm{M}$ of the MEK inhibitor UO126 followed by VK1 treatment (100 and $200 \mu \mathrm{M}$ ) for $48 \mathrm{~h}$, no induction of P-ERK 1/2 was observed. Therefore, as for Bax and Bcl-2 proteins, the addition of UO126 blocked 


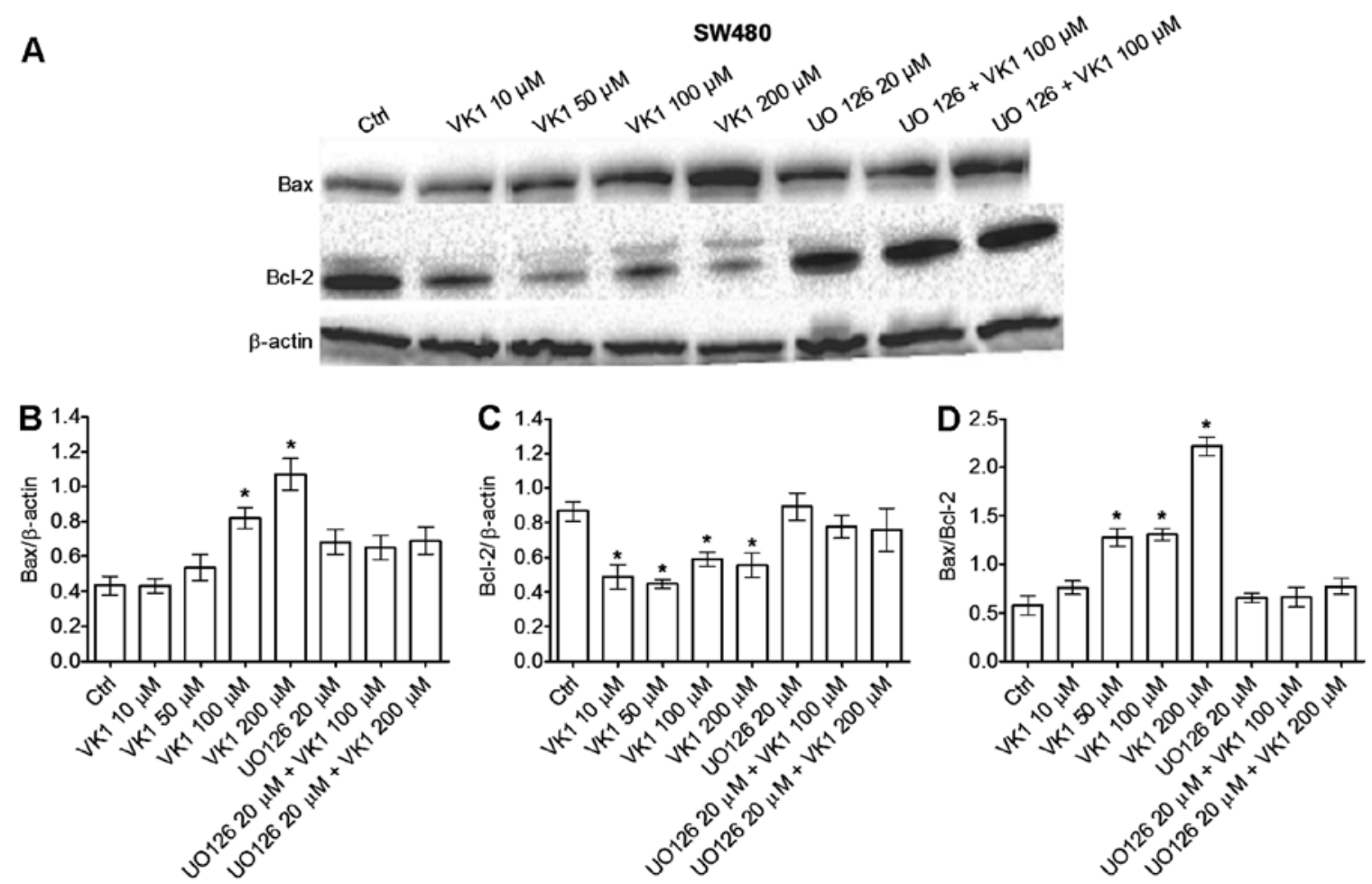

Figure 3. Western blot analysis of Bax and Bcl-2 in SW480 cell line after $48 \mathrm{~h}$ of vitamin K1 (VK1) treatment. The cells were exposed to increasing concentrations of VK1 $(10,50,100$ and $200 \mu \mathrm{M}), 20 \mu \mathrm{M}$ UO126 alone or in combination with 100 and $200 \mu \mathrm{M} \mathrm{VK} 1$. Immunoreactive bands were quantified using Quantity One Programme. The diagrams (B-D) show quantification of the intensity of bands, calibrated to the intensity of $\beta$-actin bands. All data represent the result of four different experiments (mean \pm SEM). Data were analyzed by Kruskal-Wallis analysis of variance and Dunn's multiple comparison test. ${ }^{*} \mathrm{P}<0.05$ compared to control cells.
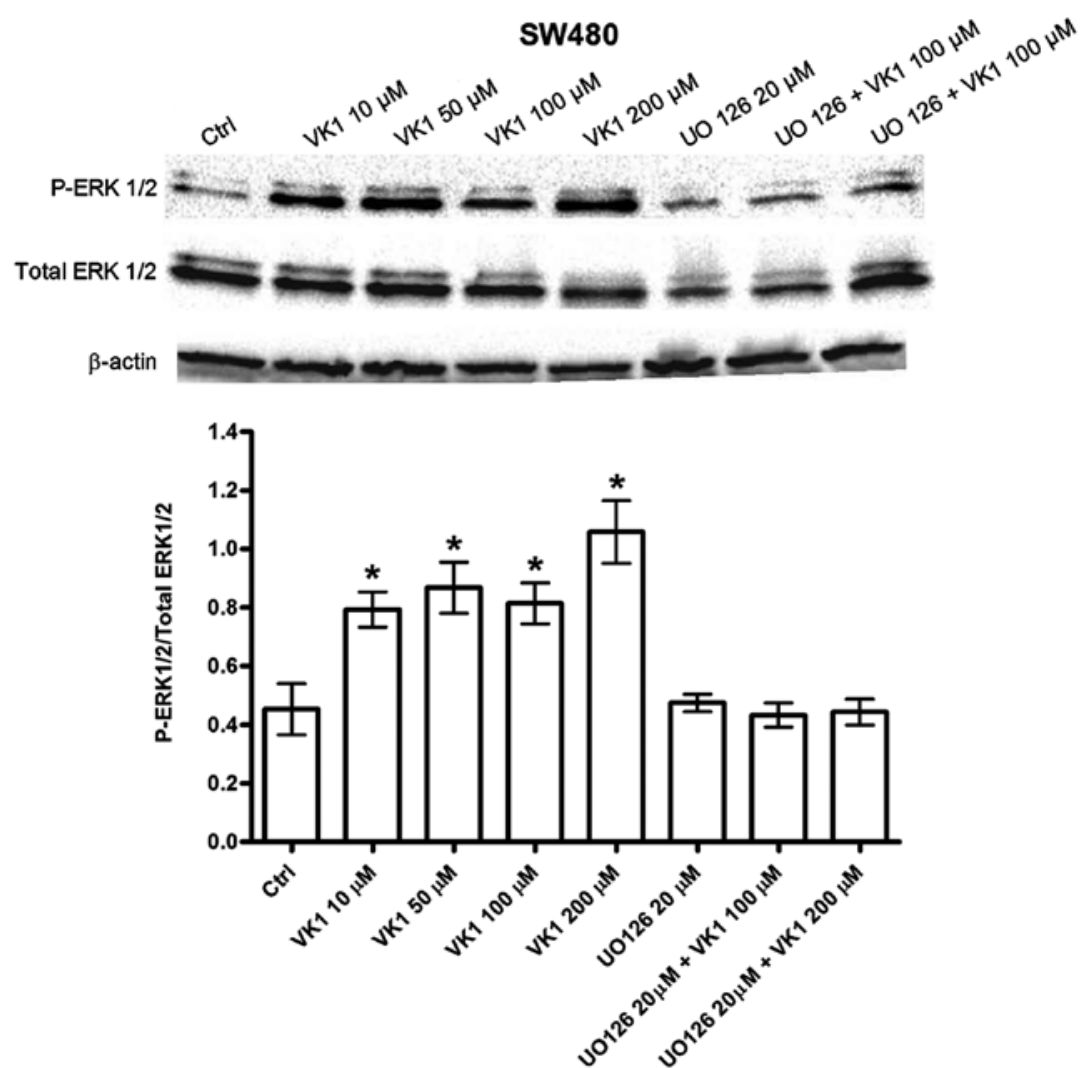

Figure 4. Western blot analysis of P-ERK1/2 and Total ERK1/2 in SW480 cell line after $48 \mathrm{~h}$ of vitamin K1 (VK1) treatment. The cells were exposed to increasing concentrations of VK1 $(10,50,100$ and $200 \mu \mathrm{M}), 20 \mu \mathrm{M}$ UO126 alone or in combination with 100 and $200 \mu \mathrm{M}$ VK1. Immunoreactive bands were quantified using Quantity One Programme. The diagram shows quantification of the intensity of bands, calibrated to the intensity of $\beta$-actin bands. All data represent the result of four different experiments (mean \pm SEM). Data were analyzed by Kruskal-Wallis analysis of variance and Dunn's multiple comparison test. ${ }^{*} \mathrm{P}<0.05$ compared to control cells. 
Table I. The polyamine profile.

\begin{tabular}{|c|c|c|c|c|c|c|}
\hline HGC-27 & & Control & $\mathrm{K} 110 \mu \mathrm{M}$ & $\mathrm{K} 150 \mu \mathrm{M}$ & $\mathrm{K} 1100 \mu \mathrm{M}$ & $\mathrm{K} 1200 \mu \mathrm{M}$ \\
\hline \multirow[t]{4}{*}{$24 \mathrm{~h}$} & Put & $0.17 \pm 0.02$ & $0.14 \pm 0.02$ & $0.14 \pm 0.03$ & $0.11 \pm 0.02$ & $0.14 \pm 0.02$ \\
\hline & Spd & $10.06 \pm 0.17$ & $9.46 \pm 0.20$ & $9.6 \pm 0.20$ & $9.53 \pm 0.09$ & $9.60 \pm 0.23$ \\
\hline & $\mathrm{Spm}$ & $17.26 \pm 0.93$ & $17.81 \pm 0.54$ & $17.03 \pm 1.0$ & $17.31 \pm 0.68$ & $17.56 \pm 0.51$ \\
\hline & Total & $27.50 \pm 0.79$ & $27.42 \pm 0.76$ & $26.77 \pm 1.7$ & $26.94 \pm 0.79$ & $27.39 \pm 0.73$ \\
\hline \multirow[t]{4}{*}{$48 \mathrm{~h}$} & Put & $0.15 \pm 0.02$ & $0.16 \pm 0.02$ & $0.21 \pm 0.02$ & $0.22 \pm 0.04$ & $0.17 \pm 0.02$ \\
\hline & Spd & $9.92 \pm 0.29$ & $8.73 \pm 0.39$ & $7.6 \pm 0.40$ & $5.81 \pm 0.22^{\mathrm{a}}$ & $5.83 \pm 0.44^{\mathrm{a}}$ \\
\hline & Spm & $17.77 \pm 0.27$ & $17.40 \pm 0.37$ & $17.87 \pm 0.14$ & $17.90 \pm 0.37$ & $16.21 \pm 0.23$ \\
\hline & Total & $27.85 \pm 0.52$ & $26.29 \pm 0.45$ & $25.65 \pm 0.72$ & $23.93 \pm 0.50^{\mathrm{a}}$ & $22.21 \pm 0.54^{\mathrm{a}}$ \\
\hline \multirow[t]{4}{*}{$72 \mathrm{~h}$} & Put & $0.18 \pm 0.01$ & $0.11 \pm 0.02$ & $0.16 \pm 0.03$ & $0.07 \pm 0.01$ & $0.04 \pm 0.01$ \\
\hline & Spd & $8.94 \pm 0.23$ & $7.04 \pm 0.31$ & $6.70 \pm 0.20$ & $4.93 \pm 0.34^{\mathrm{a}}$ & $4.25 \pm 0.22^{\mathrm{a}}$ \\
\hline & $\mathrm{Spm}$ & $19.01 \pm 0.28$ & $16.77 \pm 0.83$ & $16.49 \pm 0.81$ & $15.17 \pm 0.31$ & $14.90 \pm 0.37$ \\
\hline & Total & $28.13 \pm 0.55$ & $23.93 \pm 0.46$ & $23.35 \pm 0.64$ & $20.17 \pm 0.44^{\mathrm{a}}$ & $19.19 \pm 0.47^{\mathrm{a}}$ \\
\hline \multicolumn{7}{|l|}{ SW480 } \\
\hline \multirow[t]{4}{*}{$24 \mathrm{~h}$} & Put & $2.10 \pm 0.19$ & $1.33 \pm 0.09$ & $0.98 \pm 0.12$ & $0.60 \pm 0.10^{\mathrm{a}}$ & $0.67 \pm 0.14^{\mathrm{a}}$ \\
\hline & Spd & $12.77 \pm 0.30$ & $11.24 \pm 0.12$ & $9.22 \pm 0.30$ & $8.01 \pm 0.40^{\mathrm{a}}$ & $7.72 \pm 0.31^{\mathrm{a}}$ \\
\hline & Spm & $12.45 \pm 0.30$ & $11.62 \pm 0.19$ & $10.30 \pm 0.30$ & $8.83 \pm 0.16^{\mathrm{a}}$ & $8.75 \pm 0.20^{\mathrm{a}}$ \\
\hline & Total & $27.32 \pm 0.77$ & $24.80 \pm 0.45$ & $20.02 \pm 0.78$ & $17.44 \pm 0.61^{\mathrm{a}}$ & $17.70 \pm 0.50^{\mathrm{a}}$ \\
\hline \multirow[t]{4}{*}{$48 \mathrm{~h}$} & Put & $1.50 \pm 0.15$ & $0.98 \pm 0.20$ & $0.67 \pm 0.10$ & $0.26 \pm 0.05^{\mathrm{a}}$ & $0.25 \pm 0.09^{\mathrm{a}}$ \\
\hline & Spd & $9.40 \pm 0.28$ & $8.20 \pm 0.37$ & $7.10 \pm 0.39$ & $5.95 \pm 0.35^{\mathrm{a}}$ & $5.20 \pm 0.50^{\mathrm{a}}$ \\
\hline & $\mathrm{Spm}$ & $12.61 \pm 0.42$ & $12.5 \pm 0.60$ & $11.70 \pm 0.20$ & $11.00 \pm 0.31^{\mathrm{a}}$ & $11.30 \pm 0.23^{\mathrm{a}}$ \\
\hline & Total & $23.51 \pm 0.50$ & $21.62 \pm 0.45$ & $19.47 \pm 0.69$ & $17.50 \pm 0.50^{\mathrm{a}}$ & $16.75 \pm 0.53^{a}$ \\
\hline \multirow[t]{4}{*}{$72 \mathrm{~h}$} & Put & $1.68 \pm 0.11$ & $1.45 \pm 0.12$ & $1.53 \pm 0.10$ & $0.80 \pm 0.12^{\mathrm{a}}$ & $0.81 \pm 0.14^{\mathrm{a}}$ \\
\hline & Spd & $6.80 \pm 0.20$ & $6.00 \pm 0.24$ & $5.82 \pm 0.20$ & $4.40 \pm 0.27^{\mathrm{a}}$ & $4.27 \pm 0.20^{\mathrm{a}}$ \\
\hline & $\mathrm{Spm}$ & $12.10 \pm 0.23$ & $11.82 \pm 0.19$ & $11.90 \pm 0.36$ & $11.1 \pm 0.15^{\mathrm{a}}$ & $10.97 \pm 0.20^{\mathrm{a}}$ \\
\hline & Total & $20.58 \pm 0.50$ & $19.27 \pm 0.48$ & $19.25 \pm 0.63$ & $16.30 \pm 0.44^{\mathrm{a}}$ & $16.02 \pm 0.50^{\mathrm{a}}$ \\
\hline
\end{tabular}

Put, putrescine; Spd, spermidine; Spm, spermine; Total, total polyamine in HGC-27 and SW480 cell lines following administration of vitamin K1 (VK1) increasing concentrations (from 10 to $200 \mu \mathrm{M}$ ) after 24, 48 and $72 \mathrm{~h}$. All data represent the results of four different experiments (mean \pm SEM). For each time of treatment data were analyzed by Kruskal-Wallis analysis of variance and Dunn's multiple comparison test, ${ }^{*} \mathrm{P}<0.05$ vs. control. Polyamines are in $\mathrm{nmol} / \mathrm{mg}$ protein.

SW480 cells from VK1 mediated induction of apoptosis, thus suggesting a contribution of the MAPK pathway in this process.

Effects of VK1 on polyamine biosynthesis. Table I shows the polyamine profile in HGC-27 and SW480 cell lines following administration of increasing VK1 concentrations up to $72 \mathrm{~h}$. VK1 treatment led to a decrease in the single and total polyamine contents in both cell lines. In detail, a significant $(\mathrm{P}<0.05)$ reduction in the spermidine and total polyamine content was observed in HGC-27 cells after $48 \mathrm{~h}$ (-41 and $-14 \%$, respectively) and $72 \mathrm{~h}(-45$ and $-28 \%$, respectively) of exposure to $\mathrm{VK} 1$ concentrations $\geq 100 \mu \mathrm{M}$ compared to control cells. In SW480 cells, the effect started after $24 \mathrm{~h}$ with VK1 concentrations $\geq 100 \mu \mathrm{M}$ that induced a significant $(\mathrm{P}<0.05)$ decrease of all the single and total polyamine levels compared to control cells. Of note, the effect persisted after 48 and $72 \mathrm{~h}$ of treatment.

The effects of VK1 administration on ODC activity and ODC expression in HGC-27 and SW480 cell lines were studied at increasing concentrations (from 10 to $200 \mu \mathrm{M}$ ) up to 72 h. As shown in Fig. 5A and B, after 72-h administration, $\mathrm{VK} 1$ concentrations $\geq 100 \mu \mathrm{M}$ significantly reduced $(\mathrm{P}<0.05)$ both ODC activity $(-74 \%)$ and ODC expression mRNA $(-50 \%)$ in HGC-27 cells compared to the control ones. Overall, the effect of reduction by VK1 in SW480 cells was more rapid, since ODC activity was significantly reduced $(\mathrm{P}<0.05)$ by $36 \%$ starting from $24 \mathrm{~h}$ of treatment with $\mathrm{VK} 1$ concentrations $\geq 50 \mu \mathrm{M}$ compared to the untreated cells (Fig. 5C). Regarding ODC expression, 24-h administration of $\mathrm{VK} 1$ concentrations $\geq 100 \mu \mathrm{M}$ caused a significant reduction $(\mathrm{P}<0.05)$ by $62.5 \%$ of ODC mRNA level compared to untreated cells (Fig. 5D). Notably, the significant effect persisted up to $72 \mathrm{~h}$.

\section{Discussion}

Along with the proven effects on bone metabolism and blood clotting, compounds belonging to VK family have also been proposed as antineoplastic factors. However, the majority of 
HGC-27
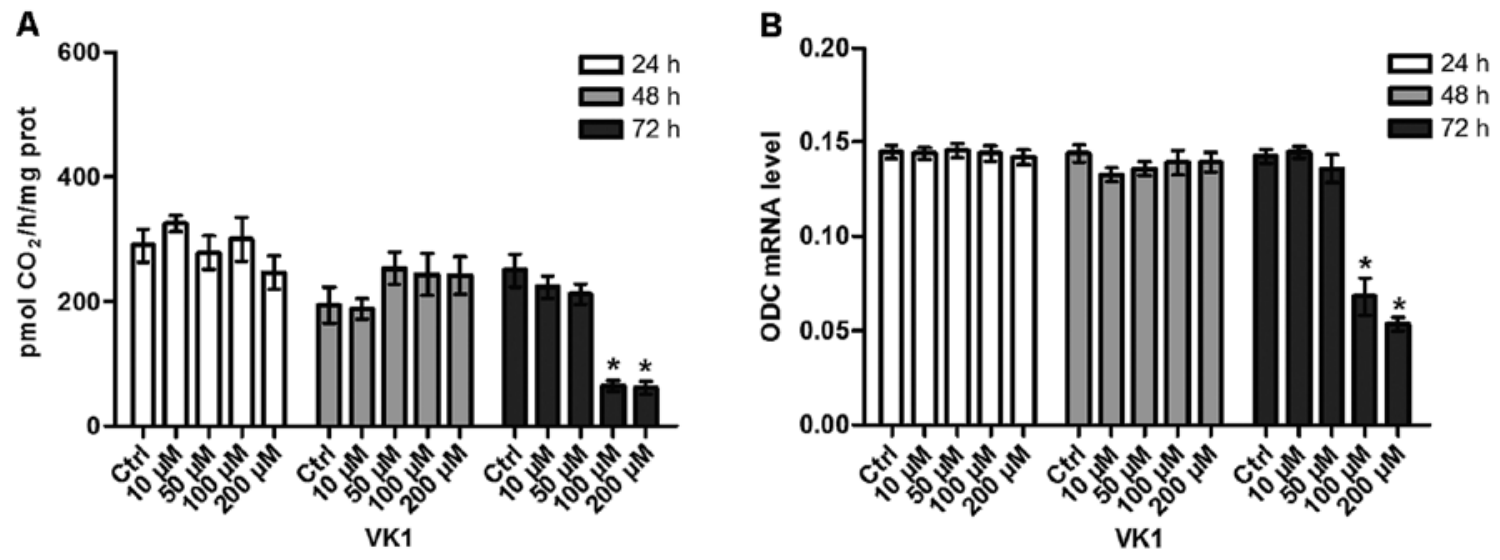

SW480
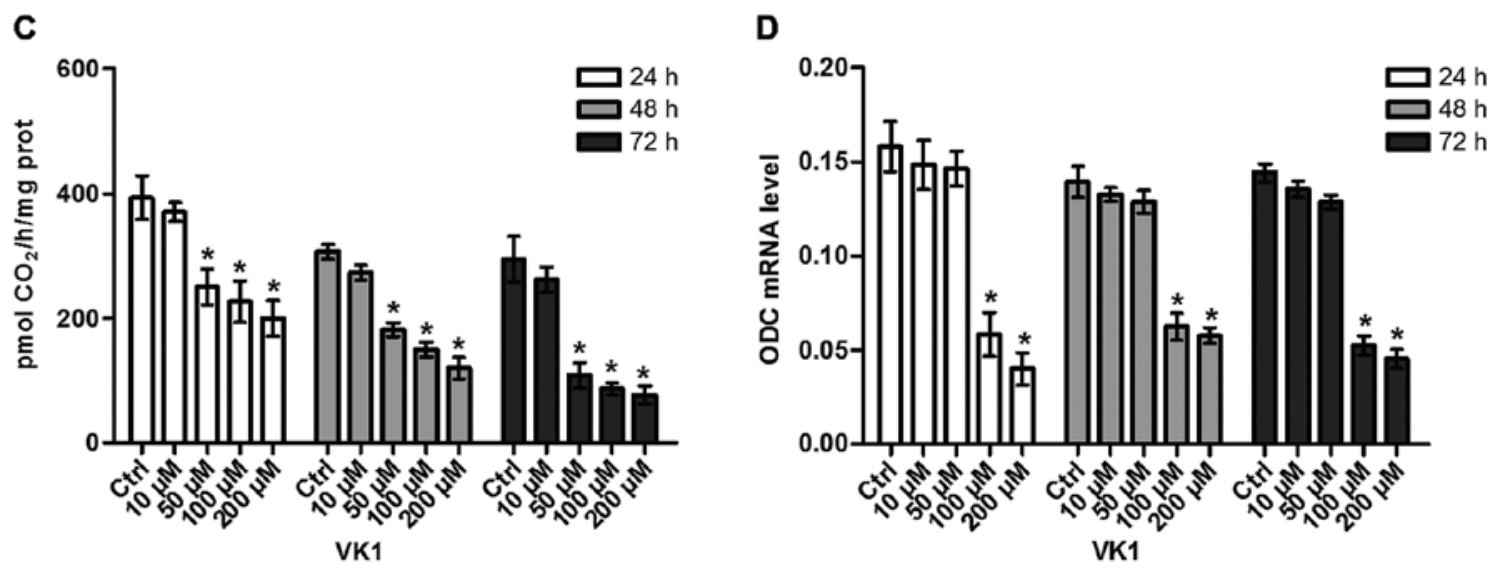

Figure 5. Ornithine decarboxylase (ODC) activity and mRNA level of HGC-27 and SW480 cell lines in response to vitamin K1 (VK1) treatment. Effects of increasing concentrations of VK1 $(10,50,100$ and $200 \mu \mathrm{M})$ on the ODC activity and mRNA level in HGC-27 (A and B) and SW480 (C and D) cell lines after 24,48 and $72 \mathrm{~h}$ of treatment. All data represent the result of four different experiments (mean \pm SEM). For each time of treatment, data were analyzed by Kruskal-Wallis analysis of variance and Dunn's multiple comparison test. ${ }^{*} \mathrm{P}<0.05$ compared to control cells.

data on this issue derives from studies performed on VK2 and VK3 and the exact mechanisms of action are still not completely elucidated $(6,31,32)$.

It has been reported that VK1 can inhibit survival and induce apoptosis in pancreatic cancer cell lines (33); it is also able to enhance sorafenib-induced growth inhibition in human hepatocellular carcinoma and malignant glioma $(12,34)$, but scarce data are available on its potential against GI neoplasms (14). Hence, one of the aims of the present research was to compare the effects of VK1 administration on growth of two different human GI cancer cell lines, one originating from undifferentiated carcinoma of the stomach (HGC-27), the other from colon adenocarcinoma (SW480) paying attention to the involvement of polyamine biosynthesis.

The main finding of the present study is that VK1 administration not only reduced cell proliferation and induced apoptosis in both HGC-27 and SW480 cells, but also caused a significant decrease in the polyamine biosynthesis. Even if the response to increasing concentrations of VK1 shown by the two GI cancer cell lines was very similar, some peculiar differences must be underlined.

Firstly, as regards cell proliferation, VK1 administration to HGC-27 cells with concentrations $\geq 100 \mu \mathrm{M}$ significantly reduced the MTT conversion after $48 \mathrm{~h}$. In SW480 cells, the inhibitory effect started rapidly after $24 \mathrm{~h}$ with the same concentration and, thus, demonstrating a more pronounced susceptibility of colonic cells to VK1 action.

Secondly, in accordance with MTT data, also the single and total polyamine levels decreased significantly after VK1 treatment in the same time-dependent manner. However, after $48 \mathrm{~h}$ of VK1 administration to HGC-27 cells, a significant reduction occurred only in the spermidine as well as total polyamine contents with the highest concentrations (100 and $200 \mu \mathrm{M}$ ). In SW480 cells, all the single and total polyamines significantly decreased already after $24 \mathrm{~h}$ of treatment with concentrations $\geq 100 \mu \mathrm{M}$.

Polyamines can be considered reliable markers of neoplastic proliferation, since abnormal hyperproliferative cells, such as those in neoplastic and pre-neoplastic tissue, exhibit very high requirements for these substances to sustain cell growth through elevated DNA, RNA and protein synthesis (18). Furthermore, it is known that polyamines influence the expression of various genes involved in cell proliferation, tumor invasion and metastatis (35). There is a vast body of literature describing the relationship between increased levels of polyamines and cancer, most of which suggests an association of induced polyamine biosynthesis with neoplasms (36). An important role is also played by ODC, a key-regulator enzyme 
in the polyamine biosynthesis, that it is now considered as a true oncogene (37).

VK1 administration induced a significant decrease in ODC activity and expression in both the gastric and colon cancer cells. In HGC-27 cell line the decrease was significant at a late stage (after $72 \mathrm{~h}$ ) with the highest concentrations (100 and $200 \mu \mathrm{M}$ ). On the contrary, in SW480 cells, a significant decrease in ODC activity occurred earlier with $50 \mu \mathrm{M}$ of VK1 after $24 \mathrm{~h}$ of treatment and this effect persisted up to $72 \mathrm{~h}$. A concomitant and significant inhibition of ODC gene expression was observed starting from $100 \mu \mathrm{M}$ of $\mathrm{VK} 1$.

Data from the present study are in agreement with published studies performed using other nutritional components such as flavonoids, polyphenols and probiotics that have demonstrated how these factors are able to reduce the polyamine biosynthesis in different cancer cells, including the GI ones (38).

Functionally, ODC is in part responsible for the variations in the single and total polyamine contents. This enzyme affects mainly spermidine and putrescine levels, that are more involved in cell proliferation than spermine; the latter is implicated essentially in cell differentiation and neoplastic transformation, with different processes engaged in maintaining its critical levels (39).

Polyamines are also pivotal in the regulation of ion transport and the stabilization of several cellular components, such as cell membranes and chromatin structure. Therefore, a reduction of the levels of these polycations might induce destabilization of important cell structures, leading to loss of cell integrity and finally inducing cell death $(39,40)$. It has been observed that the depletion of polyamines by treatment with the ODC inhibitor, difluoromethylornithine (DFMO), resulted in growth inhibition leading to a significant increase in apoptosis by altering both Bax and Bcl-2 expression $(41,42)$.

Based on the above, the inhibitory effect on polyamine biosynthesis by VK1 could also be linked to the observed increase of apoptosis. VK1 concentrations $\geq 100 \mu \mathrm{M}$ also induced apoptosis in both cell lines after $48 \mathrm{~h}$ of treatment, as indicated by the significant increase in the Bax/Bcl-2 ratio of mRNA levels. However, in HGC-27 no significant changes in Bax and Bcl-2 proteins occurred, probably due to the fact that VK1 exerted its effects on the modulation of gene expression without any consequence on the protein structure in this cell line. In the contrary, the increase in Bax/Bcl-2 ratio of mRNA levels in SW480 cells was caused by a significant increase in the pro-apoptotic Bax protein levels and a significant decrease in the anti-apoptotic Bcl-2 protein levels.

As regards the possible involvement of the MAPK pathway in the apoptotic process, treatment with VK1 showed a significant dose-dependent increase in ERK phosphorylation, with a peak increase after $48 \mathrm{~h}$ in SW480 cells, but not in HGC-27 ones. Of note, when SW480 cells were simultaneously co-treated with a MEK inhibitor and VK1, the induction of ERK phosphorylation was prevented and VK1-mediated induction of apoptosis was blocked, indicating the participation of the MAPK pathway in this process.

Although it is accepted that ERK pathway stimulates cell growth and protects cells from death (43), our findings agree with reports in literature proposing new interpretations of the ERK phosphorylation. Zhu et al (44) demonstrated a proapoptotic role of the ERK pathway in T-cells where the inhibition of
ERK phosphorylation antagonized apoptosis. Similar results were obtained by Showalter et al (13) in a study performed on pancreatic cancer cell lines treated with either VK1 or VK2 administered at inhibitory doses. ERK phosphorylation was also induced by two VK analogs in different cancer cells and had a strong correlation with the growth-inhibitory effect (45). The increase in ERK phosphorylation could be closely linked to the decrease in polyamine contents observed after VK1 treatment. Previous studies have shown that the inhibitory effect on polyamine biosynthesis by DFMO treatment increases ERK phosphorylation and signaling through the MAPK pathway in human breast cancer cells (46).

Finally, a caspase-dependent induction in apoptosis induced by VK1 was not observed in the cell lines, since western blot analysis revealed no active products of caspase-3, an executioner caspase, and caspase-9, an initiator caspase. Even if caspases are established players of apoptosis in various models, increasing evidence demonstrates that apoptosis may be induced without their activation (47).

In conclusion, to the best of our knowledge, this is the first study aimed at comparing the effects of the naturally occurring VK1 on gastric and colorectal cancer cell growth and exploring its mechanisms of action. Our findings show an inhibition of cell proliferation and induction of apoptosis involving polyamine biosynthesis and MAPK pathway. Moreover, this evidence indicates a different proliferative behavior and a different response to VK1 by gastric and colon cancer cells, with the latter showing a more pronounced susceptibility to VK1 action. This cell line demonstrated growth ability closely linked to the high capacity of de novo polyamine biosynthesis and polyamine uptake (48). This evidence supports the hypothesis that VK1 may have different effects on different types of cell lines.

Although future studies are needed to better elucidate the exact mechanisms underlying VK1 anticancer properties and to check these effects also in in vivo models, our preliminary data imply potential for novel therapeutic strategies. VK1 is safe and without known toxicities in adult humans (49), so it could be effective in prevention and treatment of selected GI neoplasms. In particular, as hypothesized for other diet components, a combined chemopreventive and therapeutical intervention using protocols based on the use of this naturally substance, along with polyamine inhibitors and/or analogues would enhance VK1 properties. This could represent a suitable alternative option for improving the efficacy of chemotherapy and chemoprevention and the management of patients with cancers of the digestive tract.

\section{References}

1. Lepage C, Hamza S and Faivre J: Epidemiology and screening of colon cancer. Rev Prat 60: 1062-1067, 2010 (In French).

2. Milner JA, McDonald SS, Anderson DE and Greenwald P: Molecular targets for nutrients involved with cancer prevention. Nutr Cancer 41: 1-16, 2001.

3. MacFarlane AJ and Stover PJ: Convergence of genetic, nutritional and inflammatory factors in gastrointestinal cancers. Nutr Rev 65: S157-S166, 2007.

4. Hitomi M, Yokoyama F, Kita Y, Nonomura T, Masaki T, Yoshiji H, Inoue H, Kinekawa F, Kurokohchi K, Uchida N, et al: Antitumor effects of vitamins K1, K2 and K3 on hepatocellular carcinoma in vitro and in vivo. Int J Oncol 26: 713-720, 2005. 
5. Amalia H, Sasaki R, Suzuki Y, Demizu Y, Bito T, Nishimura H, Okamoto Y, Yoshida K, Miyawaki D, Kawabe T, et al: Vitamin $\mathrm{K} 2$-derived compounds induce growth inhibition in radioresistant cancer cells. Kobe J Med Sci 56: E38-E49, 2010.

6. Ogawa M, Nakai S, Deguchi A, Nonomura T, Masaki T, Uchida N, Yoshiji H and Kuriyama S: Vitamins K2, K3 and $\mathrm{K} 5$ exert antitumor effects on established colorectal cancer in mice by inducing apoptotic death of tumor cells. Int J Oncol 31: 323-331, 2007.

7. Lamson DW and Plaza SM: The anticancer effects of vitamin K. Altern Med Rev 8: 303-318, 2003.

8. Shearer MJ and Newman P: Metabolism and cell biology of vitamin K. Thromb Haemost 100: 530-547, 2008.

9. Yao Y, Li L, Zhang H, Jia R, Liu B, Zhao X, Zhang L, Qian G, Fan X and Ge S: Enhanced therapeutic efficacy of vitamin K2 by silencing BCL-2 expression in SMMC-7721 hepatocellular carcinoma cells. Oncol Lett 4: 163-167, 2012.

10. Ozaki I, Zhang H, Mizuta T, Ide Y, Eguchi Y, Yasutake T, Sakamaki T, Pestell RG and Yamamoto K: Menatetrenone, a vitamin K2 analogue, inhibits hepatocellular carcinoma cell growth by suppressing cyclin D1 expression through inhibition of nuclear factor kappaB activation. Clin Cancer Res 13: 2236-2245, 2007.

11. Kanamori T, Shimizu M, Okuno M, Matsushima-Nishiwaki R, Tsurumi H, Kojima S and Moriwaki H: Synergistic growth inhibition by acyclic retinoid and vitamin $\mathrm{K} 2$ in human hepatocellular carcinoma cells. Cancer Sci 98: 431-437, 2007.

12. Du W, Zhou JR, Wang DL, Gong K and Zhang QJ: Vitamin K1 enhances sorafenib-induced growth inhibition and apoptosis of human malignant glioma cells by blocking the Raf/MEK/ERK pathway. World J Surg Oncol 10: 60, 2012.

13. Showalter SL, Wang Z, Costantino CL, Witkiewicz AK, Yeo CJ, Brody JR and Carr BI: Naturally occurring $\mathrm{K}$ vitamins inhibit pancreatic cancer cell survival through a caspase-dependent pathway. J Gastroenterol Hepatol 25: 738-744, 2010.

14. Orlando A, Linsalata M, Tutino V, D'Attoma B, Notarnicola M and Russo F: Vitamin K1 exerts antiproliferative effects and induces apoptosis in three differently graded human colon cancer cell lines. BioMed Res Int Article ID 296721 (In press).

15. Tokita H, Tsuchida A, Miyazawa K, Ohyashiki K, Katayanagi S, Sudo H, Enomoto M, Takagi Y and Aoki T: Vitamin K2-induced antitumor effects via cell-cycle arrest and apoptosis in gastric cancer cell lines. Int J Mol Med 17: 235-243, 2006.

16. Kawakita H, Tsuchida A, Miyazawa K, Naito M, Shigoka M, Kyo B, Enomoto M, Wada T, Katsumata K, Ohyashiki K, et al Growth inhibitory effects of vitamin K2 on colon cancer cell lines via different types of cell death including autophagy and apoptosis. Int J Mol Med 23: 709-716, 2009.

17. Igarashi $\mathrm{K}$ and Kashiwagi $\mathrm{K}$ : Modulation of cellular function by polyamines. Int J Biochem Cell Biol 42: 39-51, 2010.

18. Moschou PN and Roubelakis-Angelakis KA: Polyamines and programmed cell death. J Exp Bot 65: 1285-1296, 2014.

19. Nowotarski SL, Woster PM and Casero RA Jr: Polyamines and cancer: implications for chemotherapy and chemoprevention. Expert Rev Mol Med 22: 15:e3, 2013.

20. Ramani D, De Bandt JP and Cynober L: Aliphatic polyamines in physiology and diseases. Clin Nutr 33: 14-22, 2014.

21. Laukaitis CM and Gerner EW: DFMO: Targeted risk reduction therapy for colorectal neoplasia. Best Pract Res Clin Gastroenterol 25: 495-506, 2011.

22. Seiler N: Thirty years of polyamine-related approaches to cancer therapy. Retrospect and prospect. Part 1 . Selective enzyme inhibitors. Curr Drug Targets 4: 537-564, 2003.

23. Linsalata $\mathrm{M}$ and Russo $\mathrm{F}$ : Nutritional factors and polyamine metabolism in colorectal cancer. Nutrition 24: 382-389, 2008

24. Linsalata M, Orlando A, Messa C, Refolo MG and Russo F: Quercetin inhibits human DLD-1 colon cancer cell growth and polyamine biosynthesis. Anticancer Res 30: 3501-3507, 2010.

25. Linsalata M, Cavallini A, Messa C, Orlando A, Refolo MG and Russo F: Lactobacillus rhamnosus GG influences polyamine metabolism in HGC-27 gastric cancer cell line: A strategy toward nutritional approach to chemoprevention of gastric cancer. Curr Pharm Des 16: 847-853, 2010.

26. MacKeigan JP, Collins TS and Ting JP: MEK inhibition enhances paclitaxel-induced tumor apoptosis. J Biol Chem 275: 38953-38956, 2000

27. Orlando A, Linsalata M, Notarnicola M, Tutino V and Russo F: Lactobacillus GG restoration of the gliadin induced epithelial barrier disruption: the role of cellular polyamines. BMC Microbiol 14: 19, 2014
28. Linsalata M, Notarnicola M, Tutino V, Bifulco M, Santoro A, Laezza C, Messa C, Orlando A and Caruso MG: Effects of anandamide on polyamine levels and cell growth in human colon cancer cells. Anticancer Res 30: 2583-2589, 2010.

29. Linsalata M, Russo F, Notarnicola M, Berloco P and Di Leo A Polyamine profile in human gastric mucosa infected by Helicobacter pylori. Ital J Gastroenterol Hepatol 30: 484-489, 1998.

30. Garewal HS, Sloan D, Sampliner RE and Fennerty B: Ornithine decarboxylase assay in human colorectal mucosa. Methodologic issues of importance to quality control. Int J Cancer 52: 355-358, 1992.

31. Kayashima T,Mori M, Yoshida H, Mizushina Y and Matsubara K 1,4-Naphthoquinone is a potent inhibitor of human cancer cell growth and angiogenesis. Cancer Lett 278: 34-40, 2009.

32. Adnan H, Antenos M and Kirby GM: The effect of menadione on glutathione S-transferase A1 (GSTA1): c-Jun N-terminal kinase (JNK) complex dissociation in human colonic adenocarcinoma Caco-2 cells. Toxicol Lett 214: 53-62, 2012.

33. Wei G, Wang M and Carr BI: Sorafenib combined vitamin K induces apoptosis in human pancreatic cancer cell lines through RAF/MEK/ERK and c-Jun NH2-terminal kinase pathways. J Cell Physiol 224: 112-119, 2010.

34. Wei G, Wang M, Hyslop T, Wang Z and Carr BI: Vitamin K enhancement of sorafenib-mediated $\mathrm{HCC}$ cell growth inhibition in vitro and in vivo. Int J Cancer 127: 2949-2958, 2010.

35. Gerner EW and Meyskens FL Jr: Polyamines and cancer: Old molecules, new understanding. Nat Rev Cancer 4: 781-792, 2004

36. Casero RA Jr and Marton LJ: Targeting polyamine metabolism and function in cancer and other hyperproliferative diseases. Nat Rev Drug Discov 6: 373-390, 2007.

37. Pegg AE: Regulation of ornithine decarboxylase. J Biol Chem 281: 14529-14532, 2006

38. Linsalata M, Orlando A and Russo F: Pharmacological and dietary agents for colorectal cancer chemoprevention: effects on polyamine metabolism (Review). Int J Oncol 45: 1802-1812, 2014.

39. Deloyer P, Peulen O and Dandrifosse G: Dietary polyamines and non-neoplastic growth and disease. Eur J Gastroenterol Hepatol 13: 1027-1032, 2001.

40. Seiler N and Raul F: Polyamines and apoptosis. J Cell Mol Med 9: 623-642, 2005.

41. Davidson NE, Hahm HA, McCloskey DE, Woster PM and Casero RA Jr: Clinical aspects of cell death in breast cancer: The polyamine pathway as a new target for treatment. Endocr Relat Cancer 6: 69-73, 1999.

42. Gao JH, Guo LJ, Huang ZY, Rao JN and Tang CW: Roles of cellular polyamines in mucosal healing in the gastrointestinal tract. J Physiol Pharmacol 64: 681-693, 2013.

43. Sui X, Kong N, Ye L, Han W, Zhou J, Zhang Q, He C and Pan H: p38 and JNK MAPK pathways control the balance of apoptosis and autophagy in response to chemotherapeutic agents. Cancer Lett 344: 174-179, 2014.

44. Zhu L, Yu X, Akatsuka Y, Cooper JA and Anasetti C: Role of mitogen-activated protein kinases in activation-induced apoptosis of T cells. Immunology 97: 26-35, 1999.

45. Osada S, Osada K and Carr BI: Tumor cell growth inhibition and extracellular signal-regulated kinase (ERK) phosphorylation by novel K vitamins. J Mol Biol 314: 765-772, 2001

46. Manni A, Washington S, Hu X, Griffith JW, Bruggeman R, Demers LM, Mauger D and Verderame MF: Effects of polyamine synthesis inhibitors on primary tumor features and metastatic capacity of human breast cancer cells. Clin Exp Metastasis 22: 255-263, 2005

47. Matsumoto K, Okano J, Nagahara T and Murawaki Y: Apoptosis of liver cancer cells by vitamin K2 and enhancement by MEK inhibition. Int J Oncol 29: 1501-1508, 2006.

48. Duranton B, Holl V, Schneider Y, Carnesecchi S, Gossé F, Raul F and Seiler N: Polyamine metabolism in primary human colon adenocarcinoma cells (SW480) and their lymph node metastatic derivatives (SW620). Amino Acids 24: 63-72, 2003.

49. Mizuta T, Ozaki I, Eguchi Y, Yasutake T, Kawazoe S, Fujimoto K and Yamamoto K: The effect of menatetrenone, a vitamin K2 analog, on disease recurrence and survival in patients with hepatocellular carcinoma after curative treatment: a pilot study. Cancer 106: 867-872, 2006. 